\title{
The Effect of Expected Losses on the Hong Kong Property Market
}

\author{
Ling $\mathrm{Li}^{1}\left[\right.$ ] Wayne Xinwei Wan ${ }^{1}[$
}

Accepted: 16 June 2021

(C) The Author(s) 2021

\begin{abstract}
Expected losses anchored to purchase prices can affect actual transactions in different property sectors. Utilizing the data of over a million commercial and residential property transactions in Hong Kong from 1991 to 2015, we find that sellers facing nominal losses relative to their prior purchase prices attained higher selling prices than their counterparts. We suggest two market factors to account for the extent of the loss effect on the market transaction prices. First, the loss effect is only prominent when comparable transaction information is not readily accessible, such as in the less-transacted commercial property market. Second, our results suggest the relevance of the loss effect to the boom-bust property cycle in both the residential and commercial markets. The effect of expected losses on transaction prices is relatively weak in the bust period between 1998 and 2003 when the Hong Kong property market lost almost two-thirds of its value, and it enlarges with the market recovering. The loss effect is not attenuated at the aggregate market level but is associated with strong reductions in price declines in the bust period and in the commercial market. These results have implications for understanding the market adjustment of the loss effect in the property market and its association with the aggregate market dynamics in a boom-bust property cycle.
\end{abstract}

Keywords Loss behavior · Anchoring · Market information · Property cycle · Commercial property $\cdot$ Residential property

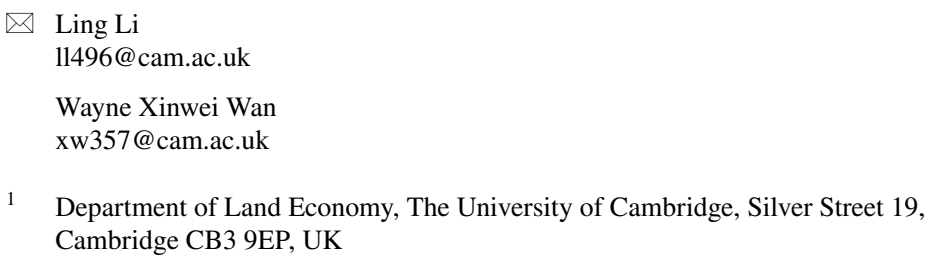




\section{Introduction}

This paper revisits the importance of expected losses in the property market. Previous literature has revealed that anchored to the initial purchase price, home sellers facing an expected loss tend to set a higher list price and exhibit a lower likelihood of sales (e.g., Andersen et al, 2021; Anenberg, 2011; Bokhari \& Geltner, 2011; Bracke \& Tenreyro, 2021; Einiö et al., 2008; Genesove \& Mayer, 2001). This loss effect, or the so-called disposition effect (Barberis, 2013), is also identified in the financial markets where investors are reluctant to sell financial assets at a loss (e.g., Chang et al, 2016; Dhar \& Zhu, 2006; Grinblatt \& Keloharju, 2001; Odean, 1998; Shefrin \& Statman, 1985). Among the efforts to account for the loss effect, loss aversion has gained the most popularity. First demonstrated by Tversky and Kahneman (1979), loss aversion refers to the tendency to consider that a loss is more painful than a gain. Hence, home sellers, due to the psychological aversion to selling their houses for less than what they initially paid, stay longer on the market with higher list prices than their counterparts. The explanation of loss aversion has quickly grown in popularity in the real estate literature with its potential to account for the stylized positive price-volume relationship, a key feature of the property market cycle (Genesove \& Mayer, 2001; Engelhardtt, 2003; Bokhari \& Geltner, 2011; Leung \& Tsang, 2013; Bao \& Meng, 2017).

The influence of expected losses anchored to purchase prices is not necessarily a reflection of loss aversion. In an efficient market, the loss aversion effect as a psychological bias should be limited to the decision of list prices and weaken or disappear with exposure to market conditions (Anenberg, 2011). For example, Genesove and Mayer (henceforth, GM) documented no significant effect of loss aversion on transaction prices, and Bokhari and Geltner (henceforth, BG), Anenberg (2011), and Zhou et al. (2020) found it to be positive but significantly weaker than that on list prices. Other established explanations to account for changes in transaction prices as a result of expected losses include equity constraints which are binding when the resale price is lower than the buying price (Stein, 1995; Genesove \& Mayer, 1997; Anderson et al., 2021) and buyers' informational constraints (Anenberg, 2016; Ben-David \& Hirshleifer, 2012). Recent studies like Bracke and Tenreyro (2021) and Zhou et al. (2021) generalized the influence of expected losses by focusing on the anchoring behavior, that is, anchoring to the price paid for the asset. They argued that the effect of expected losses on transaction prices is likely a result of insufficient adjustments due to multiple forces such as psychological loss aversion and/or informational and financial constraints.

In this study, we follow the strategy of Zhou et al. (2021) to investigate the pricing effect of expected losses by using the influential empirical model developed by GM, while we extend the literature by considering the role of two market factors in adjusting the loss effect. First, we consider the role of market information. Without perfect information, home sellers subject to expected losses are likely to fish a buyer who will pay more than the market value, though at the cost of staying longer on the market (Anenberg, 2016; Clapp et al., 2018). If the loss effect on transaction prices is due to limited information of the buyer, then we 


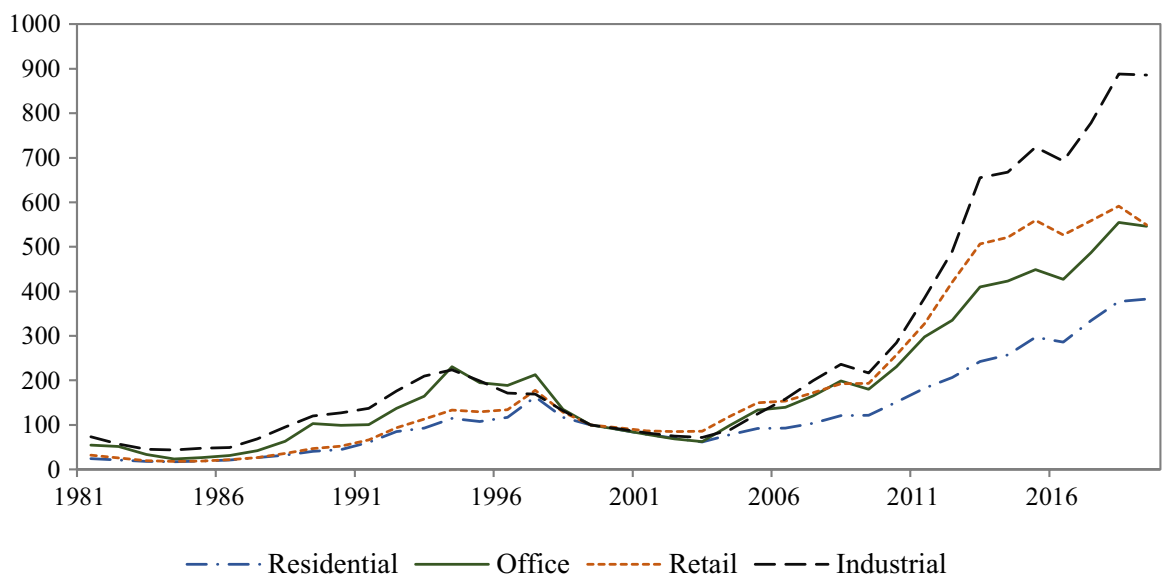

Fig. 1 Hong Kong Property Price Indices by Sectors: 1981-2019. Note: Raw data from Rating and Valuation Department of Hong Kong

expect a mitigating effect of better market information. Second, we relate the loss effect to the property market cycle. Selling prices may stick to list prices for the sake of psychologically-based anchoring behavior (Ling et al., 2018; Northcraft \& Neale, 1987) or signalling for private information (Yavas \& Yang, 1995), but they may also deviate from list prices due to rational search and bargain (Carrillo, 2013; Han \& Strange, 2016). As a reflection of bargaining between sellers and buyers, the negotiated premiums on expected losses should vary with the boombust property cycle. As expected, BG and Zhou et al. (2021) documented significant cyclicality in the effects of expected losses on transaction prices.

In line with GM, we regard the prior nominal purchase price as the reference point around which sellers are sensitive to gains and losses. In estimating the effect of expected losses on transaction prices, we follow GM's approach to address the entangling of unobserved property characteristics. This concern can be further alleviated by the interaction between the loss effect and the market condition that does not vary the valuation of unobserved quality. We utilize a rich dataset from the Hong Kong property market which consists of over 1 million sales from four major sectors-residential, industrial, office, and retail, with approximately half a million pairs of repeat sales identified. To our knowledge, this is the first study on loss behaviors that encompasses both homeowners of residential properties and professional investors of commercial properties. The sample period spans over two decades, including a large boom-bust market cycle as shown in Fig. 1.

Overall, our results from reduced-form regressions add to the literature with new evidence on how expected losses anchored to purchase prices affect transaction prices in different sectors of the property market. First of all, our findings suggest a mitigating effect of comparable market information on the influence of expected losses over transaction prices by cross-sector and within-sector comparisons of the loss effects. Close to GM's findings, the residential sector presents a positive loss effect on transaction prices in the upper bound, while 
it turns insignificant in the lower bound with unobserved quality controlled. In comparison, the three commercial sectors report significantly positive loss effects in the lower bound, consistent with the U.S. evidence provided by BG. Considering that only $10 \%$ of the total property transaction volumes are from the three commercial sectors, we ascribe the stronger loss effect on transaction prices of commercial properties to the lack of comparable transaction information. The argument is further supported by a negative crossing effect between the loss effect and a variable of comparable transaction information within each property sector.

Secondly, we find that the loss effect on individual transaction prices decreases with buyers' bargaining power, that is, stronger during market booms than during market downturns. This relationship holds across the four property sectors. In the bust period between 1998 and 2003 when the Hong Kong property market lost two thirds of its value, we observe the weakest loss effect, along with the largest presence of sellers subject to potential losses. The loss effect on transaction prices increased when the market recovered and started to boom after 2009, with a small pool of loss-facing sellers. It is also noteworthy that the association between the loss effect and the market cycle is relatively weak in the retail and office sectors. This is possibly caused by the limited number of transactions in these two smaller market sectors, which should be further investigated with better quality of commercial data in future studies.

Lastly, we establish the relevance of the seller loss behavior to the market cycle at the aggregate market levels. We mainly follow the approach of Zhou et al. (2021) to investigate the effect of expected losses on the aggregate property price indices and several distinct findings were presented. The aggregate loss effect is revealed to be stronger in the retail and office sectors than in the residential sector, and larger in the bust period than in the boom period. That is, the loss effect is associated with reduced price declines in the market trough, particularly in the commercial property market. While existing studies, such as Glaeser and Nathanson (2017) and Bracke and Tenreyro (2021), suggested that anchoring to past transaction prices is associated with excess volatility in the property market, our evidence joins Zhou et al. (2021) to support the opposite.

Given no asking price information, we rely on the variations in the effects of expected losses on transaction prices to disentangle under what conditions could the loss effect carry through the negotiation process. In addition, the findings on the influence of the seller loss behaviour on the aggregate property market suggest an important channel to understand the price volatility of the boom-bust cycle, particularly in the commercial sector. The rest of the paper proceeds as follows. The next section develops the estimation strategy, and Sect. 3 describes the unique dataset with summary statistics. Baseline results following GM are presented in Sect. 4. Section 5 reports the loss effect across sectors and its interaction with comparable transaction information. Sections 6 and 7 establish the relevance of the loss effect to the market cycle at the micro and aggregate levels. The last section concludes. 


\section{Empirical Models}

We estimate the effect of expected losses on transaction prices following the models proposed by GM and BG, with several specific modifications made to suit the characteristics of our dataset. The estimation can be summarized in two stages. In the first stage, we estimate the expected market selling price of the property using a hedonic pricing model and calculate potential losses that the seller may incur. In the second stage, we estimate the effect of potential losses on the final transaction price, with potential biases from unobserved housing features controlled.

Using the full sample of transaction records in each property sector, the expected selling price of property $i$ in district $j$ at time $t$ is derived from the following hedonic regression model:

$$
\log \left(P_{i j t}\right)=X_{i j}^{\prime} \beta+\varphi_{j t}+\varepsilon_{i j t}
$$

where the dependent variable uses the log form of the transaction price $\left(P_{i j t}\right) . X_{i j}$ denotes a set of controls for physical housing features, such as building age, unit area, floor, and distances to the closest seacoast, hospital, bus stops, MTR stations, and parks. ${ }^{1}$ We include both the first order and the second order terms for these controls to capture the nonlinear relationships. Hong Kong is divided into 57 districts by the Land Registry of Hong Kong. We use $\varphi_{j t}$ to denote the year times district fixed effects to control spatially and time-varying characteristics that are not easy to observe. Using the coefficients estimated from Eq. (1), we are able to derive a predicted market value of this property specifically at time $t$, that is, the expected selling price. We denote this expected selling price in log form as $\mu_{i j t}$. Considering the previous purchase price $\left(P_{i j, t-1}\right)$ of the property as the reference point to the seller, the expected loss of the seller is therefore defined as the difference between the previous purchase price and expected selling price, truncated below at zero:

$$
\operatorname{Loss}_{i j t}=\left\{\begin{array}{c}
\log \left(P_{i j, t-1}\right)-\mu_{i j t}, \log \left(P_{i j, t-1}\right)-\mu_{i j t}>0 \\
0, \log \left(P_{i j, t-1}\right)-\mu_{i j t} \leq 0
\end{array}\right.
$$

To estimate the effect of expected losses on the transaction price, we then regress the transaction price in the log form on the expected losses using the following specification:

$$
\log \left(P_{i j t}\right)=\gamma \operatorname{Loss}_{i j t}+\delta \mu_{i j t}+C_{i j t}^{\prime} \theta+\epsilon_{i j t}
$$

Specifically, we add the expected selling price $\mu_{i j t}$ at the right-hand side and include a vector of additional controls $\left(C_{i j t}\right)$, such as the months since the last transaction and the district times year fixed effects. The coefficient estimate of $\gamma$ thus represents the price difference between the expected selling price and transaction price that is driven by expected losses.

\footnotetext{
${ }^{1}$ For the model of residential properties, we include additional controls such as the housing estate type (i.e., single building or multiple buildings) and the number of total housing units within the estate.
} 
As discussed by GM, two major issues threaten the validity of the estimate of the loss effect on property price. We illustrate how these two issues biased our estimate in Eq. (3). The first issue is the unobserved housing features that we failed to include in Eq. (1). We assume these unobservables to be fixed over time and denoted as $v_{i j}$. Ignoring these factors may bias the estimation of the expected selling price in the hedonic model. Specifically, the real expected selling prices $\left(\mu_{i j t}\right)$ should be given by:

$$
\tilde{\mu}_{i j t}=X_{i j}^{\prime} \beta+\varphi_{j t}+v_{i j}
$$

The second potential bias is from the under- or over-payment relative to the expected price when the seller originally purchases the unit, and we denote it as $w_{i j, t-1}$. Since the hedonic model of Eq. (1) also holds for the previous transaction, we have:

$$
\log \left(P_{i j, t-1}\right)=X_{i j}^{\prime} \beta+\varphi_{j, t-1}+v_{i j}+w_{i j, t-1}
$$

Combining Eqs. (3) - (5), the real expected loss of the seller $\left(\operatorname{Loss}_{i j t}\right)$ at time $t$ is thus expressed as:

$$
\tilde{\operatorname{Loss}}_{i j t}=\log \left(P_{i j, t-1}\right)-\tilde{\mu}_{i j t}=\varphi_{j, t-1}-\varphi_{j t}+w_{i j, t-1}
$$

Substituting Eqs. (4) and (6) into Eq. (3), the unbiased model to estimate the loss effect on property prices is given as:

$$
\log \left(P_{i j t}\right)=\gamma\left(\varphi_{j, t-1}-\varphi_{j t}+w_{i j, t-1}\right)+\delta\left(X_{i j}^{\prime} \beta+\varphi_{j t}+v_{i j}\right)+C_{i j t}^{\prime} \theta+\epsilon_{i j t}
$$

Since both $w_{i j, t-1}$ and $v_{i j}$ are unobservable, this reflects that our estimate of $\gamma$ in Eq. (3) is biased. To address these issues, we follow the adjustment method proposed by GM and BG. Firstly, we still use the noisy measure of the expected loss as in Eq. (2). Secondly, we include the residuals from Eq. (1) as an additional control in Eq. (3). Expanding and rewriting the adjusted Eq. (3) will end up with an equivalent model to Eq. (7). ${ }^{2}$ This means that the corresponding coefficient of $\gamma$ in the adjusted model serves as the lower bound for the true effect of expect losses, conditional on the assumption that the first residual captures the unobserved features. If buyers with expected losses are selling at higher prices, then a positive estimate of $\gamma$ is expected.

\section{Data}

Our data comes from EPRC Limited, which covers all transactions of residential properties in Hong Kong from 1993 to 2015, as well as of retail, industrial and office properties from 1991 to 2014. This dataset provides detailed information on repeat transactions, including the transaction prices, dates, and the names of buyers and sellers. It also includes comprehensive information on physical characteristics,

\footnotetext{
2 The details of derivation can be referred to GM and BG.
} 
including address, unit size, floor, and property type. Using the public geographic data of amenities from ESRI China (Hong Kong) Limited and the tool of ArcGIS, we geocoded the property addresses and calculated the distances between the property and the closest MTR station, bus stop, seacoast, school, university, hospital, and park. The initial dataset contains over 1 million property transactions. To address the potential entry errors in the sample, we filtered the transactions with prices lower than 0.1 million HKD and discarded transactions with incomplete information on the transaction details and physical features. For the commercial properties, the unit sizes are truncated at the top $1 \%$ to remove the outliers. The filtered transaction sample is utilized in the hedonic pricing regression of the first stage, i.e., Eq. (1), to generate estimates of predicted selling price and the results are reported in Appendix Table B1. In general, the hedonic models provide a good interpretation of the log of the property sales price. The attributes included can explain $67 \%$ of the variations of retail transaction prices, while that number exceeds $80 \%$ in the other three sectors.

Since we are interested in the effect of expected nominal losses from the previous purchase price on the subsequent selling price, we further restricted our sample to transactions paired with a previous sale with the same buyer name as the seller name of the target sale. The residential market has the most repeat sales, with $49.6 \%$ of the total transactions paired with a previous sale in the secondary market. ${ }^{3}$ The percentage is $48.4 \%$ in the industrial and office property sectors. The retail properties are the least frequently transacted in terms of repeat sales, with the percentage to be $39 \%$. In the sample of repeat sales, the holding period of the seller is defined as the number of months between consecutive transactions of the same property. To address the impact of property flippers, we excluded transactions with a holding period of less than a year. After filter, the repeat sales sample includes 413,263 residential transactions, 31,374 industrial transactions, 14,566 office transactions, and 6,572 retail transactions.

Table 1 provides summary statistics of the repeat sales sample by property sectors. As shown in Panel A, the average subsequent transaction price for a residential property is 3.46 million HKD (equivalent to approximately 0.44 million USD), and the average age is about 18 years old with an average size of 521 square feet. In Hong Kong with extreme density, the average residential property is located at the 15th floor and comes from an estate consisting of over 2,000 housing units that are more or less homogeneous. Panels B to D summarize the repeat sales in the industrial, office, and retail property sectors. The average transaction prices are 2.37 million HKD, 4.63 million HKD, and 4.83 million HKD, respectively, and the average sizes are 16,744 square feet, 999 square feet, and 409 square feet. Compared across sectors, the average holding period of a residential property is 66 months, more than a year shorter than holding a commercial property.

As stated in the empirical strategy, we apply a noisy proxy for the expected nominal loss of the seller, i.e., Loss, using the difference between the log of the predicted transaction price and the log of the previous transaction price. Table 1 also distinguishes the seller by the variable of Loss Dummy, which is equal to 1 if the predicted transaction

\footnotetext{
${ }^{3}$ Considering the different pricing mechanisms in the primary and secondary property market, we exclude repeat sales paired with a previous purchase from property developers.
} 


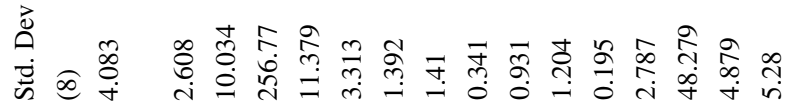

$\stackrel{6}{\infty}$

8े

है

II

言

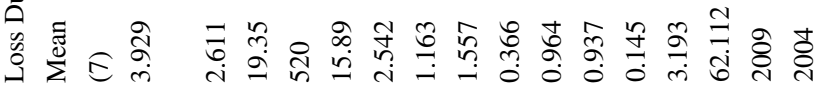
离

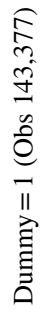

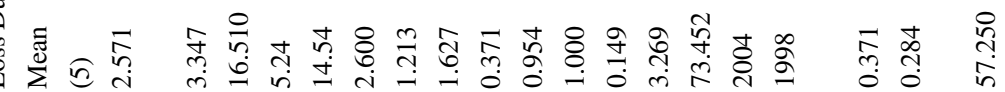

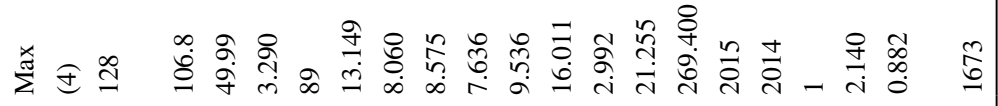

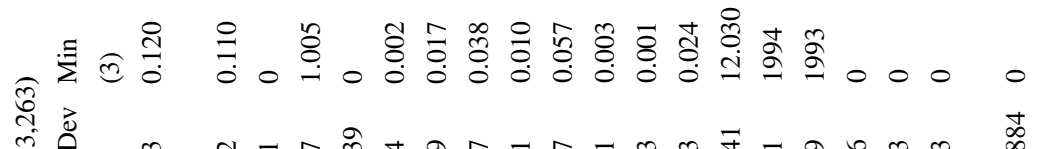

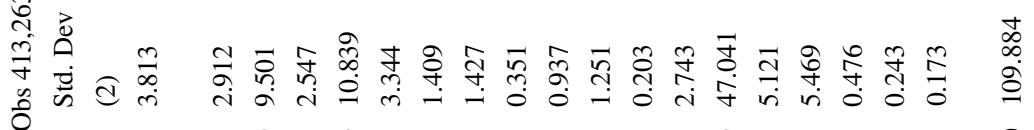

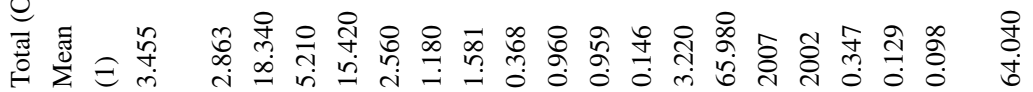

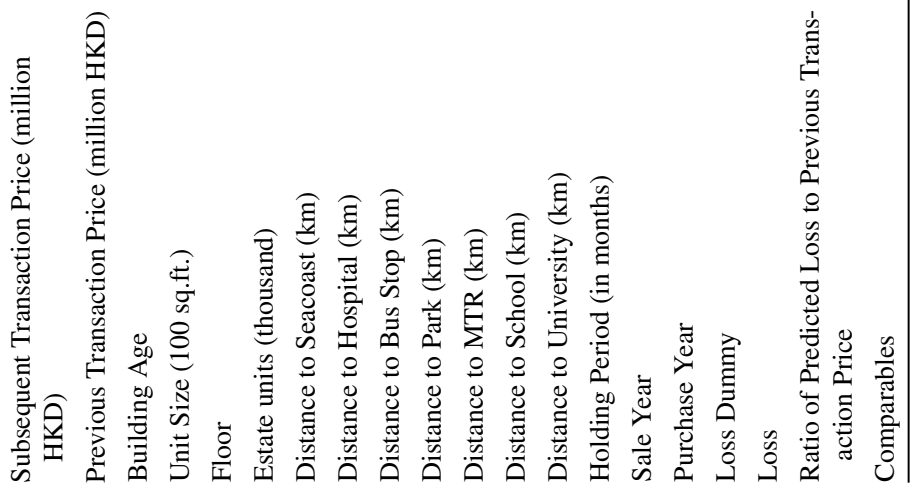




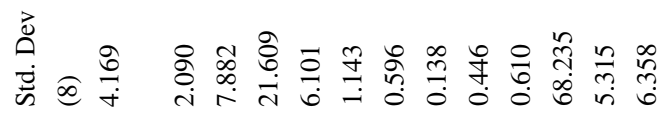

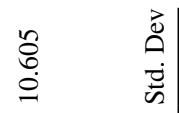

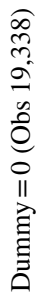

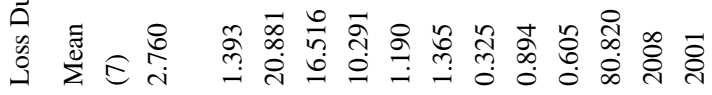

$\stackrel{8}{\circ}$

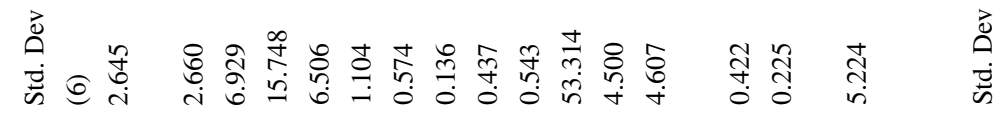

రి

$\widehat{\widehat{d}}$

ôे

oิ

斑

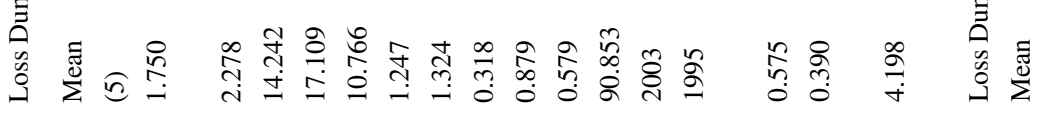

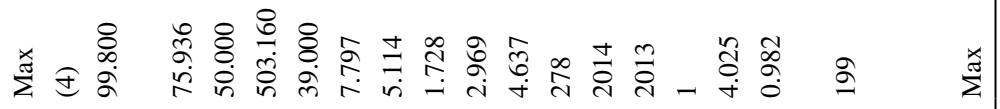
吉

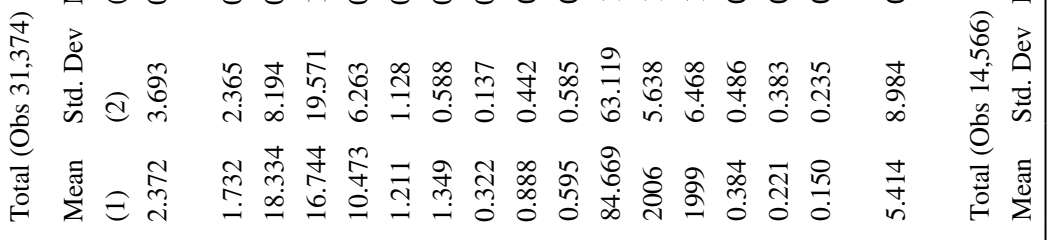

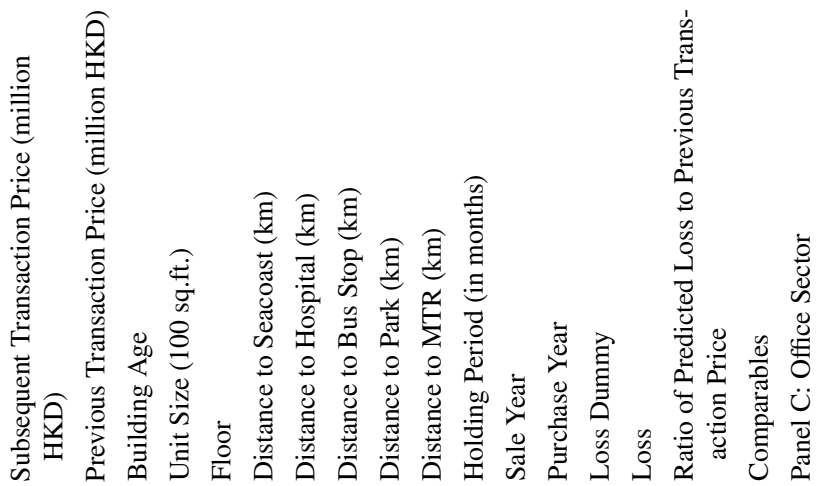




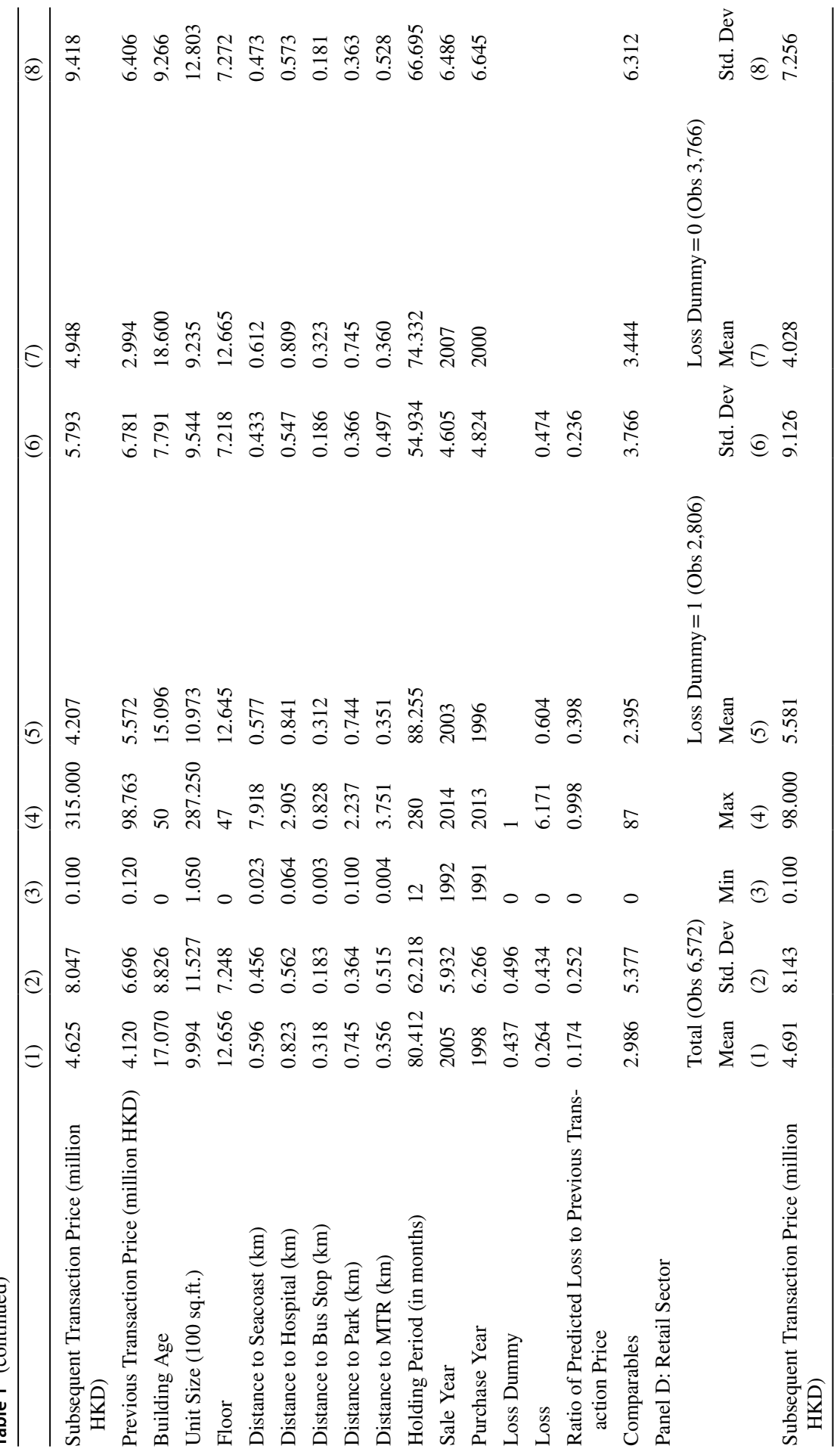




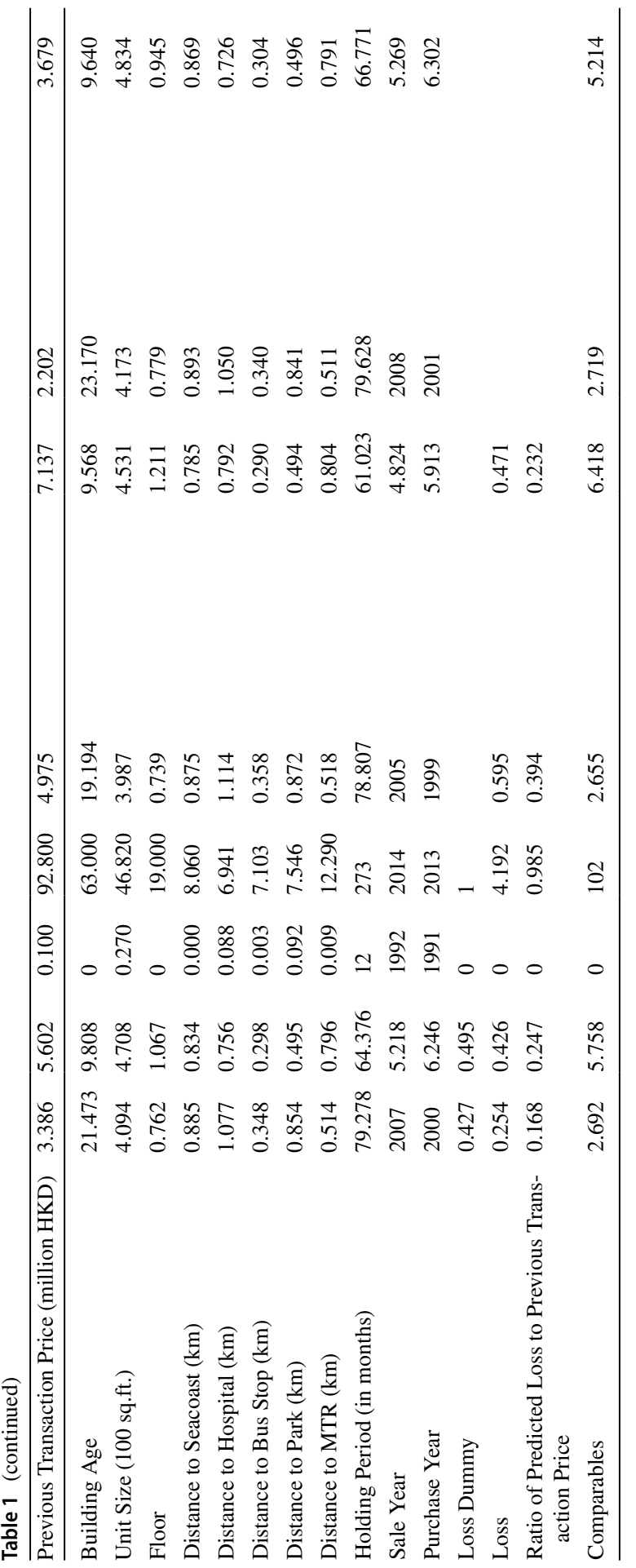


Table 2 Baseline Results of the Loss Effect

\begin{tabular}{|c|c|c|c|c|}
\hline & \multicolumn{4}{|l|}{ Residential } \\
\hline & (1) & (2) & (3) & (4) \\
\hline & $\log$ (price) & $\log ($ price $)$ & $\log ($ price $)$ & $\log$ (price) \\
\hline \multirow[t]{2}{*}{ Loss } & $0.2238^{* * *}$ & 0.0029 & $0.0424^{* * *}$ & $0.0912^{* * *}$ \\
\hline & $(0.0206)$ & $(0.0101)$ & $(0.0122)$ & $(0.0102)$ \\
\hline \multirow[t]{2}{*}{ Loss Squared } & & & $-0.0463^{* * *}$ & \\
\hline & & & $(0.0135)$ & \\
\hline \multirow[t]{2}{*}{ Estimated Value } & $0.9809^{* * *}$ & $0.9657^{* * *}$ & $0.9659^{* * *}$ & $0.9561^{* * *}$ \\
\hline & $(0.0174)$ & $(0.0132)$ & $(0.0132)$ & $(0.0171)$ \\
\hline \multirow[t]{2}{*}{ Residuals from Last Sale } & & $0.4518^{* * *}$ & $0.4504^{* * *}$ & \\
\hline & & $(0.0138)$ & $(0.0136)$ & \\
\hline \multirow[t]{2}{*}{ Adjusted Residuals } & & & & $0.3710^{* * * *}$ \\
\hline & & & & $(0.0168)$ \\
\hline \multirow[t]{2}{*}{ Holding Period } & $-0.0004^{* * *}$ & $-0.0010^{* * * *}$ & $-0.0010^{* * *}$ & $-0.0002^{* * *}$ \\
\hline & $(3.5 \mathrm{E}-05)$ & $(4.5 \mathrm{E}-05)$ & $(4.6 \mathrm{E}-05)$ & $(3.0 \mathrm{E}-05)$ \\
\hline Year * District FEs & $\mathrm{Y}$ & $\mathrm{Y}$ & $\mathrm{Y}$ & $\mathrm{Y}$ \\
\hline Observations & 413,263 & 413,263 & 413,263 & 252,474 \\
\hline R-squared & 0.918 & 0.932 & 0.932 & 0.928 \\
\hline
\end{tabular}

Loss is defined as the difference between the log of the predicted transaction price and the log of the previous transaction price, truncated below at zero. Adjusted Residuals are the residuals of the previous transaction price from the first-stage hedonic pricing regression by utilizing a subsample with transactions occurred in the boom periods between 1993 and 1997 and between 2009 and 2015. Robust standard errors are clustered at district level. ***,**,* denote for $1 \%, 5 \%$ and $10 \%$ significance, respectively

price is smaller than the previous transaction price and 0 otherwise. We compare the housing features and transaction details between sellers facing expected losses (Loss Dummy $=1)$ and expected gains (Loss Dummy=0). In the residential sector, approximately one third of the sellers are facing expected losses in the study period, which is much less than the level $(50-55 \%)$ in the Boston housing market documented by GM. In general, the distributions of physical housing features are balanced between transactions predicted with losses and with gains apart from age. The average holding period of loss-facing sellers is over 11 months longer than that of gain-facing sellers, suggesting that loss-facing sellers have a longer time on the market. In the commercial sectors, the percentage of sellers subject to expected losses are $38.4 \%$ for industrial properties, $43.7 \%$ for office properties, and $42.7 \%$ for retail properties. This is much higher than the $22-25 \%$ level identified by BG in the commercial property market of the U.S.

\section{The Effects of Expected Losses on Subsequent Transaction Prices}

Table 2 presents the baseline results of discerning the loss effect in the residential sector following GM. As shown in Column (1), the log transaction price is the dependent variable, with the estimated value of the property and holding months 
since the last sale as the regressors. According to GM, Column (1) registers the upper bound of the loss effect with the assumption of no unobservable characteristics. That is, a one-percent increase in nominal loss is associated with $0.22 \%$ increase in the subsequent transaction price. When the variable of residuals from the last sale was included in Column (2) to control for unobserved quality, the coefficient estimate on Loss documents the lower bound on the true loss effect. Consistent with the findings of GM, the lower bound of loss effect is small and insignificant. Column (3) adds a quadratic loss term to test the diminishing effect of large expected losses, as examined by GM. The results show that both the linear loss term and the quadratic loss term are significant, and the estimates imply a positive but decreasing marginal response to the expected loss.

According to Anenberg (2011), GM's estimation strategy introduces a bias in the measurement of unobservable housing quality because of omitting the loss effect in the first stage hedonic regression. We follow Anenberg's (2011) approach to produce a variable of adjusted residuals as the proxy for unobserved quality. Specifically, we restrict the sample used in the first stage to housing transactions that occurred in boom periods, that is, between 1993 and 1997 and between 2009 and 2015. Given the large price increases during these periods as shown in Fig. 1, it is reasonable to assume that sellers are less likely to face nominal losses. Because facing losses is rare during these hot markets, the unobserved quality measured by the residual is less likely to contain the loss effect. By utilizing the restricted sample, we generate adjusted residuals by repeating the hedonic pricing regression in the first stage. The period restriction in the first stage further limits the sample in the second stage to housing transactions of which the previous sale occurred between 1993 and 1997 or between 2009 and 2015. Given this requirement on the previous sale, approximately $60 \%$ of the repeat sales sample remain in the second stage. In Column (4) of Table 2, we repeat Eq. (7) with the variable of Adjusted Residuals, and the coefficient estimate on the Loss variable is positive and significant, falling in the range of the lower and upper bounds following GM's approach. Considering that Anenberg's (2011) approach requires a restrictive repeat sales sample, it may not be applicable to the commercial sectors with relatively limited transactions. Since the revised loss effect is above the GM's lower bound, we can argue that the true loss effect is larger than what was identified by using GM's lower-bound approach.

\section{The Loss Effects and the Market Information}

The property market is characterized by imperfect information due to its uniqueness and high transaction costs associated. Property buyers rely heavily on transaction details of comparable properties to evaluate the pricing of the target property (Anenberg, 2016). More transactions of comparable properties enable ordinary buyers to reduce the mispricing of target properties. That is, sellers facing nominal losses would be less likely to fish a buyer with an irrational high 
price. In this section, we try to quantify the importance of comparable transaction information in reducing the loss effect.

\section{Across-sector Evidence}

We rely on the number of comparable transactions to measure how informative a market is. To begin with, we compare the loss effect across property sectors of different sizes. In Hong Kong, the residential market is the most frequently traded sector. It occupied $90 \%$ of the entire property transaction volume with an average of over 80,000 transactions per year between 1995 and 2014 (see Appendix Table B2). The three commercial sectors - retail, industrial, and office-as a whole only constitute $10 \%$ of the total transaction volume over the same period, making it difficult to find comparable transactions for deciding the price of the target commercial property. Therefore, our hypothesis is that the loss effect on list prices should be more likely to carry through to transaction prices in the three commercial sectors than in the residential market.

Also, we further divide the residential market into the mass market (housing units with a saleable floor area of below 1,000 square feet) and the luxury market (housing units with a saleable floor area of above or equal to 1,000 square feet). The mass units are the dominant housing type in Hong Kong, accounting for $95 \%$ of the residential transactions that occurred between 1995 and 2014. Likewise, our hypothesis is that fewer comparable transactions should be available for purchasing a luxury unit, thus enabling the loss effect to be realized on transaction prices.

Table 3 reports the results of Eq. (7) by utilizing samples across the five property sectors. To our knowledge, BG is the only exception to examine the loss effect in the commercial property market. Without differentiating the sectors, they documented an overall increase of $2.45 \%$ in transaction prices per $10 \%$ increase in nominal loss. As shown in the first Column of Panel A, we obtain a similar loss effect in the retail sector. It suggests that a seller facing a nominal loss of $10 \%$ receives a $2.57 \%$ higher price on average, and the effect is statistically significant at the $1 \%$ significance level. The loss effect decreases by around half in the office and industrial sectors where a larger pool of sales is available to search for comparable transactions. In line with the prediction, the loss effect dissipates considerably in the residential sector. In the luxury housing market, the loss effect registers to be positive- $10 \%$ nominal losses are associated with $0.18 \%$ higher transaction prices, whereas it turns negligible for mass housing units. ${ }^{4}$

One potential concern is that Hong Kong's residential property market has consistent high demand and insufficient supply (Leung, 2015), which may also affect the influence of the seller loss behavior on transaction price. Nevertheless, it will not undermine our argument that the loss behavior will have a smaller impact on transaction prices in the residential sector than in the commercial sectors, due to more

\footnotetext{
${ }^{4}$ It is possible that the difference in the loss aversion effects between the mass and luxury housing markets may be caused by different compositions of sellers. The results, as shown in Appendix TableB3, remain robust when we repeat the regressions for mass and luxury housing markets by excluding company sellers, which may behave differently compared with homeowners.
} 
Table 3 Loss Effects Across Four Property Sectors in Hong Kong

\begin{tabular}{|c|c|c|c|c|c|}
\hline & $\begin{array}{l}\text { Retail } \\
\log (\text { price })\end{array}$ & $\begin{array}{l}\text { Office } \\
\log \text { (price) }\end{array}$ & $\begin{array}{l}\text { Industrial } \\
\log \text { (price) }\end{array}$ & $\begin{array}{l}\text { Residential: Luxury } \\
\log \text { (price) }\end{array}$ & $\begin{array}{l}\text { Residential: Mass } \\
\log \text { (price) }\end{array}$ \\
\hline Panel A & (1) & (2) & (3) & (4) & (5) \\
\hline Loss & $\begin{array}{l}0.2568^{* * *} \\
(0.0639)\end{array}$ & $\begin{array}{l}0.1451^{* * *} \\
(0.0380)\end{array}$ & $\begin{array}{l}0.1098^{* * *} \\
(0.0221)\end{array}$ & $\begin{array}{l}0.0177 \\
(0.0274)\end{array}$ & $\begin{array}{l}-0.0002 \\
(0.0097)\end{array}$ \\
\hline Estimated Value & $\begin{array}{l}1.0683^{* * *} \\
(0.0222)\end{array}$ & $\begin{array}{l}1.0174^{* * *} \\
(0.0137)\end{array}$ & $\begin{array}{l}1.0233^{* * *} \\
(0.0125)\end{array}$ & $\begin{array}{l}0.9155^{\text {*** }} \\
(0.0257)\end{array}$ & $\begin{array}{l}0.9498^{* * *} \\
(0.0157)\end{array}$ \\
\hline Residuals from Last Sale & $\begin{array}{l}0.6994^{* * *} \\
(0.0224)\end{array}$ & $\begin{array}{l}0.7444^{* * *} \\
(0.0117)\end{array}$ & $\begin{array}{l}0.6770^{* * *} \\
(0.0209)\end{array}$ & $\begin{array}{l}0.5241^{* * *} \\
(0.0358)\end{array}$ & $\begin{array}{l}0.4459^{* * *} \\
(0.0141)\end{array}$ \\
\hline Holding Period & $\begin{array}{l}-0.0016^{* * *} \\
(0.0003)\end{array}$ & $\begin{array}{l}-0.0004^{* * *} \\
(0.0001)\end{array}$ & $\begin{array}{l}-0.0003^{* * *} \\
(0.0001)\end{array}$ & $\begin{array}{l}-0.0007^{* * *} \\
(0.0001)\end{array}$ & $\begin{array}{l}-0.0010^{* * *} \\
(4.4 \mathrm{E}-05)\end{array}$ \\
\hline Year * District FEs & $\mathrm{Y}$ & $\mathrm{Y}$ & $\mathrm{Y}$ & $\mathrm{Y}$ & $\mathrm{Y}$ \\
\hline Observations & 6,572 & 14,566 & 31,374 & 18,711 & 394,552 \\
\hline R-squared & 0.849 & 0.933 & 0.915 & 0.884 & 0.918 \\
\hline Panel B & (1) & (2) & (3) & (4) & $(5)$ \\
\hline Loss & $\begin{array}{l}0.3952^{* * *} \\
(0.0538)\end{array}$ & $\begin{array}{l}0.0670^{* *} \\
(0.0282)\end{array}$ & $\begin{array}{l}0.1525^{* * *} \\
(0.0231)\end{array}$ & $\begin{array}{l}0.0382^{* * *} \\
(0.0123)\end{array}$ & $\begin{array}{l}0.0141^{* * *} \\
(0.0023)\end{array}$ \\
\hline Loss $*$ Comparables & $\begin{array}{l}-0.0435^{* * *} \\
(0.0092)\end{array}$ & $\begin{array}{l}0.0228 \\
(0.0136)\end{array}$ & $\begin{array}{l}-0.0082^{* * *} \\
(0.0020)\end{array}$ & $\begin{array}{l}-0.0038^{* * * *} \\
(0.0010)\end{array}$ & $\begin{array}{l}-0.0002^{* * *} \\
(2.0 \mathrm{E}-0.5)\end{array}$ \\
\hline Year * District FEs & $\mathrm{Y}$ & $\mathrm{Y}$ & $\mathrm{Y}$ & $\mathrm{Y}$ & $\mathrm{Y}$ \\
\hline Observations & 6,572 & 14,566 & 31,374 & 18,711 & 394,552 \\
\hline R-squared & 0.855 & 0.934 & 0.915 & 0.884 & 0.918 \\
\hline
\end{tabular}

Residential: Luxury refers to transactions of housing units with saleable floor area of above or equal to 1,000 square feet; Residential: Mass refers to transactions of housing units with saleable floor area of below 1,000 square feet. Comparables measures the number of comparable transactions in the same building (estate for residential properties) as the target property in a quarter before the target transaction. Robust standard errors are clustered at district level. ***, **, * denote for $1 \%, 5 \%$ and $10 \%$ significance, respectively

comparable transactions and higher market efficiency. Particularly, if the homebuyers in Hong Kong are price takers due to high demand and low supply, it is expected that homebuyers will accept the high listing prices proposed by the loss-facing sellers. In that case, the impact of seller loss behavior on transaction prices in the residential market is expected to become larger. However, even with this potential impact from the supply-side restrictions, we still find that the loss effect is smaller in the residential market than in the other commercial sectors. Thus, it shows that the channel of market information that we identify dominates the potential impact of the supply-side restrictions.

Another potential limitation is that the unobserved variations in property features within districts may potentially bias the loss coefficients we estimate. While our results of residential transactions remain robust if we include the estate and year fixed effects instead (see Appendix Table B4), this empirical specification could not be implemented for the commercial properties. Therefore, the large coefficients of 
expected losses in the thinner commercial sectors might be explained by more unobserved features of commercial properties. Nevertheless, our within-sector evidence and cross-cycle evidence, which are presented in following sections, are less likely to be biased due to the unobserved quality.

\section{Within-sector Evidence}

We carry out a second step to further explore whether comparable transactions play a role in reducing the loss effect. For each transaction, we calculate the number of comparable transactions (i.e., Comparables) in a quarter before the target transaction. A quarter window is allowed for two reasons. First, the pre-determined measurement of Comparables mitigates the endogeneity concern. Second, considering the fast changes in the property market, more recent the transactions, more informative they could be. In the residential sector, we select comparable transactions based on two criteria: coming from the same estate with the target transaction and of the same size category (i.e., mass or luxury housing unit). Housing units within the same estate share the same location and neighborhood facilities, ${ }^{5}$ and they provide the closest substitutes for each other (Wong et al., 2020). Because the format of estates only exists in the residential market, we revise the comparable criteria for commercial properties to transactions in the same building that occurred in the previous quarter. We interact the Loss variable with Comparables to test the counteraction effect of comparable transaction information. As shown in Panel B of Table 3, we obtain a negative and statistically significant interaction estimate between the Loss variable and the Comparables variable except for the office sector. That is to say, comparable transaction information is useful in mitigating the loss effect in the retail, industrial, and residential sectors. ${ }^{6}$

\section{The Loss Effects and the Market Cycles}

We hypothesize that whether sellers facing nominal losses could fetch a higher price than their counterparts should also depend on the market heat. In hot markets, home sellers have greater bargaining power in the negotiation than buyers and transaction prices tend to stick to sellers' asking price (Carrillo, 2013). That suggests a great possibility for the loss effect to carry through to actual transactions. When the property market experiences continuous declines, buyers gain the bargaining power to set the price (Han \& Strange, 2016). Although sellers are more likely to face nominal losses in downward periods, they are limited by their bargaining power to achieve any loss effect in actual sale prices.

\footnotetext{
${ }^{5}$ However, there are exceptions. Some residential estates in Hong Kong are developed in different phases, which are not located in the exact same location. For such estates, we calculate the comparable transactions by estate phases.

6 All results remain robust if we use a dummy variable to denote the existence of comparable transactions, as reported in Appendix Table B5.
} 


\section{Five Distinct Periods of the Market Cycle}

To test the relevance of the loss effect to the market heat, we break down the cycle of the Hong Kong property market between 1991 and 2015. As shown in Fig. 1, the period through 1997 depicted the first stable and increasing property market across the four sectors. The year 1997 is a transition year coincided with the Asian financial crisis and the sovereignty return of Hong Kong to China, followed by a sudden crash of the whole market. The industrial and office sectors started the crash three years before 1997. ${ }^{7}$ With the epidemic of SARS in 2003, all sectors reached the bottom with about one third of the price at the last peak. Afterwards, the property market recovered gradually from the bottom and most sectors (except for residential) went back to its pre-crisis level before the global financial crisis (GFC) hit in 2008. Unlike the U.S. and U.K. property markets that lost $20 \%$ of the value in the GFC, the Hong Kong market experienced an approximately $10 \%$ price decline which is limited to the industrial and office sectors. Soon the whole market regained the momentum of increase and has begun to shoot new records with rapid increases year by year. At the end of 2015, the residential sector increased by almost 4 times compared with the price at the trough of 2003, while the office and retail sectors witnessed an increase of 6 times and the industrial sector skyrocketed to 10 times of its price in 2003. Therefore, the Hong Kong property market can be divided into five distinct periods: two boom periods (i.e., before $1997^{8}$ and after 2009), two bust periods (between 1998 and 2003 and the year of 2008) and a recovery period (i.e., between 2004 and 2007).

\section{Descriptive Statistics}

We start with descriptive statistics on sales by the market cycle as reported in Table 4. In general, sales subject to expected nominal losses or Loss sales are closely related to the boom-and-bust cycle. First, the share of Loss sales and the magnitude of losses exhibit a negative relationship with the heat of the market. In the residential sector, 90\% of repeat sales face expected losses in the bust period between 1998 and 2003. This figure is 56\% in the recovery period and $25 \%$ in the year of GFC. Given that the residential sector suffered little price decline in the GFC as shown in Fig. 1, it is not surprising to obtain a relatively small share of Loss sales in 2008. The Loss share further declines to 18\% and 10\% in the two boom periods before 1997 and after 2009, respectively. Likewise, the magnitude of nominal losses (on average) is considerably higher in the bust and recovery periods than in the boom periods. Similar patterns present in the three commercial sectors but in different degrees. The interaction of

\footnotetext{
7 Possible reasons for the early decline in the industrial and office sectors include the oversupply of industrial properties due the China's open-door policy in the late $70 \mathrm{~s}$ and the early retreat of investors in non-residential sectors before the Handover (Chau, 1997). Because of the Handover, industrialists moved their production base to Mainland China leaving behind a lot of vacant industrial buildings in Hong Kong, some of which were used illegally as offices, which also depressed office prices. This may explain the co-movements of the industrial and office sectors between 1994 and 1997.

${ }^{8}$ For the purpose of comparison, we define the bust period as between 1997 and 2003 for all sectors. This makes the period before 1997 not entirely a boom period for the industrial and office sectors.
} 
Table 4 Key Statistics by the Hong Kong Market Cycle

\begin{tabular}{|c|c|c|c|c|c|}
\hline & $\begin{array}{l}\text { Before } 1997 \\
\text { Boom } \\
\text { Mean }\end{array}$ & $\begin{array}{l}\text { 1998-2003 Bust } \\
\text { Mean }\end{array}$ & $\begin{array}{l}2004- \\
2007 \\
\text { Recovery } \\
\text { Mean }\end{array}$ & $\begin{array}{l}2008 \text { GFC } \\
\text { Mean }\end{array}$ & $\begin{array}{l}\text { After } 2009 \text { Boom } \\
\text { Mean }\end{array}$ \\
\hline Residential & (1) & (2) & (3) & (4) & (5) \\
\hline $\begin{array}{l}\text { Share of Loss } \\
\text { Sales (Loss >0) }\end{array}$ & $18.28 \%$ & $89.51 \%$ & $55.53 \%$ & $24.90 \%$ & $9.92 \%$ \\
\hline $\begin{array}{l}\text { Loss conditional } \\
\text { on Loss }>0\end{array}$ & 0.131 & 0.466 & 0.346 & 0.237 & 0.125 \\
\hline Holding Period & 26.30 & 48.27 & 72.77 & 72.33 & 73.76 \\
\hline $\begin{array}{l}\text { Holding Period of } \\
\text { Loss Sales (a) }\end{array}$ & 24.04 & 49.19 & 90.46 & 111.90 & 101.79 \\
\hline $\begin{array}{l}\text { Holding Period of } \\
\text { Gain Sales (b) }\end{array}$ & 26.81 & 40.43 & 50.68 & 59.21 & 70.67 \\
\hline (a)-(b) & -2.77 & 8.76 & 39.78 & 52.69 & 31.12 \\
\hline Industrial & (1) & (2) & (3) & (4) & (5) \\
\hline $\begin{array}{l}\text { Share of Loss } \\
\text { Sales (Loss >0) }\end{array}$ & $47.33 \%$ & $93.80 \%$ & $49.40 \%$ & $20.72 \%$ & $11.05 \%$ \\
\hline $\begin{array}{l}\text { Loss conditional } \\
\text { on Loss }>0\end{array}$ & 0.151 & 0.790 & 0.260 & 0.055 & 0.027 \\
\hline Holding Period & 31.97 & 79.32 & 94.23 & 96.00 & 95.30 \\
\hline $\begin{array}{l}\text { Holding Period of } \\
\text { Loss Sales (a) }\end{array}$ & 35.21 & 78.84 & 124.92 & 139.35 & 92.66 \\
\hline $\begin{array}{l}\text { Holding Period of } \\
\text { Gain Sales (b) }\end{array}$ & 29.06 & 38.31 & 64.28 & 84.67 & 95.63 \\
\hline (a)-(b) & 6.15 & 40.53 & 60.64 & 54.68 & -2.97 \\
\hline Office & (1) & (2) & (3) & (4) & (5) \\
\hline $\begin{array}{l}\text { Share of Loss } \\
\text { Sales (Loss }>0)\end{array}$ & $31.77 \%$ & $92.97 \%$ & $56.62 \%$ & $29.68 \%$ & $19.00 \%$ \\
\hline $\begin{array}{l}\text { Loss conditional } \\
\text { on Loss }>0\end{array}$ & 0.090 & 0.856 & 0.321 & 0.105 & 0.051 \\
\hline Holding Period & 30.26 & 72.37 & 91.29 & 94.63 & 97.2 \\
\hline $\begin{array}{l}\text { Holding Period of } \\
\text { Loss Sales (a) }\end{array}$ & 29.89 & 73.94 & 114.55 & 128.39 & 100.03 \\
\hline $\begin{array}{l}\text { Holding Period of } \\
\text { Gain Sales (b) }\end{array}$ & 30.44 & 51.56 & 60.93 & 80.39 & 96.54 \\
\hline (a)-(b) & -0.55 & 22.38 & 53.62 & 48 & 3.49 \\
\hline Retail & (1) & (2) & (3) & (4) & (5) \\
\hline $\begin{array}{l}\text { Share of Loss } \\
\text { Sales (Loss }>0)\end{array}$ & $40.63 \%$ & $72.57 \%$ & $51.91 \%$ & $41.46 \%$ & $29.08 \%$ \\
\hline $\begin{array}{l}\text { Loss conditional } \\
\text { on Loss }>0\end{array}$ & 0.195 & 0.584 & 0.333 & 0.246 & 0.152 \\
\hline Holding Period & 32.58 & 63.48 & 80.38 & 73.87 & 94.08 \\
\hline $\begin{array}{l}\text { Holding Period of } \\
\text { Loss Sales (a) }\end{array}$ & 31.55 & 64.68 & 88.19 & 79.92 & 88.65 \\
\hline $\begin{array}{l}\text { Holding Period of } \\
\text { Gain Sales (b) }\end{array}$ & 33.29 & 60.31 & 71.96 & 69.59 & 96.30 \\
\hline
\end{tabular}


Table 4 (continued)

\begin{tabular}{llllll}
\hline & Before 1997 & 1998-2003 Bust & $2004-$ & 2008 GFC & After 2009 Boom \\
Boom & Mean & $\begin{array}{l}2007 \\
\text { Recovery } \\
\text { Mean }\end{array}$ & & Mean & \\
& & & 16.23 & 10.33 & -7.65 \\
\hline (a)-(b) & -1.74 & 4.37 & Mean & \\
\hline
\end{tabular}

Loss sales and the property cycle in the retail sector is not as strong as in the other sectors. Specifically, the difference in the share of Loss sales between the bust period (1998-2003) and the boom period (after 2009) is approximately $40 \%$ in the retail sector in comparison with around $80 \%$ in the residential and industrial sectors and $74 \%$ in the office sector. Through the cycle, the retail sector also presents much flatter variations in the magnitude of expected nominal losses. In addition, because the industrial and retail sectors started the first market crash from 1994 rather than from 1997, they contain an exceptionally large Loss share in the boom period before 1997.

Second, we divide the sample conditional on expected losses and gains and find that the holding periods of Loss sales are more sensitive to the cycle than those with expected gains or Gain sales. When comparing holding periods, we focus on the periods after 1997 that are less biased. ${ }^{9}$ Moving from the bust to the boom periods, the average holding period of Gain sales increases steadily by around 10 months per period across sectors, while that of Loss sales see more radical increases as well as declines. For example, in the industrial sector, the average holding period of Loss sales is 79 months in the bust period between 1998 and 2003, and it shot to 125 months in the recovery period and peaked at the GFC period with 139 months, before dropping by over 40 months in the boom period after 2009. Likewise, we find a much weaker sensitivity of the average holding period of Loss sales to the cycle in the retail sector. As a result of different sensitivities of the average holding period between Loss sales and Gain sales, we observe the holding back behaviour of Loss sales to vary with the cycle. Consistent with Zhou et al. (2021), we find the Loss sales to be sold relatively quickly in the boom period compared to the bust and recovery periods in all four property sectors. ${ }^{10}$

Taken together, the descriptive statistics suggest significant cyclicality in the loss behavior in terms of the share of Loss sales, the magnitude of losses, and the willingness to sell measured by the holding period.

\footnotetext{
9 The lack of early transaction data prevents us from fully identifying repeat sales occurred before 1997. For example, the average holding period of residential sales before 1997 is approximately two years, while that is six years in the next boom period. The concern is not fully alleviated in the following bust period between 1998 and 2003 considering that there remains a discrepancy of one to two years in the average holding periods with the rest periods. In addition, the implementation of Special Stamp Duty in 2012 that prevents short sales would possibly cause the sample in the boom period after 2009 to be different. Because we have removed repeat sales with a holding period less than a year, the average holding period in the boom period after 2009 is not substantially affected.

${ }^{10}$ In the residential sector, the difference between Loss sales and Gain sales in the bust period between 1998 and 2003 is only 9 months, while it reaches 53 months during the year of GFC. We attribute it to the exclusion of long-holding Loss sales in the bust period. As comparison, we limit repeat sales within a holding period of 10 years, and the difference between Loss sales and Gain sales reduces to 16 months in the GFC period and turns negative in the boom period after 2009.
} 


\section{Regression Results}

We verify the aforementioned cyclicality in sellers' loss behavior by regressions. Specifically, we run Eq. (7) separately by using subsamples of different periods and Table 5 presents the results across the four property sectors. In general, we find that the loss effect on transaction prices is larger in the period of market booms than in the period of market downturns. As shown in Panel A of Table 5, in the residential sector, the coefficient estimates on Loss are statistically significant and, interestingly, different across the periods. The first boom period between 1993 and 1997 registers the largest loss effect-a seller facing a nominal loss of $10 \%$ receives a $2.01 \%$ higher price on average (Column (1)), nearly a triple of that in the second boom period after 2009 (Column (5)). When the market started to recover from the bust, $10 \%$ of nominal losses are only associated with a higher price of $0.428 \%$ (Column (3)). The loss effect in the GFC period (Column (4)) is slightly smaller than the recovery period. However, in the bust period between 1998 and 2003, sellers subject to nominal losses accepted a price lower than the average. Specifically, a onepercent increase in the nominal losses is associated with a higher transaction price of $0.243 \%$.

Similar findings of the loss effects across the periods, according to the results from Panel B and Panel C, are observed in the three commercial sectors. ${ }^{11} \mathrm{Nev}-$ ertheless, it is worthy to note that the pattern of loss effect increasing with the market heat is less clear in the retail sector as shown in Panel D of Table 5. This is consistent with the finding from the descriptive statistics suggesting a weak interaction of the loss behavior and the property cycle in the retail sector.

We consider two robustness tests of the loss effect. First, since our sample period ends in 2015 and we can only observe long-holding sellers in the earlier periods, it is concerned that different loss effects over the cycle may be ascribed to different holding periods of the repeat sales. We alleviate this concern by repeating the tests in Table 5 but limiting the holding period within 10 years. The results are reported in Appendix Table B7. We find that, with the repeat sales sample to be more comparable across the cycle, variations in the loss effects strengthen in the residential and industrial sectors with relatively frequent transactions.

Second, noticing the nonlinear loss effect identified in Column (3) of Table 2, we also test the cyclicality of the loss effect by focusing on small losses. Appendix Tables B8 and B9 present the results when the ratio of predicted loss to the previous transaction price is limited to be less than 0.2 and 0.1 , respectively. In general, with losses being restricted, we find the coefficient estimates of the Loss variable to be large and significant, and the patterns over the cycle remain more stable in the

\footnotetext{
11 We repeat the tests for the industrial and office sectors by adjusting the cut-off year of market cycle and the results remain. Results are provided in the Appendix Table B6.
} 
Table 5 Loss Effects Across the Hong Kong Market Cycle

\begin{tabular}{|c|c|c|c|c|c|}
\hline & $\begin{array}{l}\text { Before } 1997 \\
\text { Boom } \\
\log (\text { price })\end{array}$ & $\begin{array}{l}\text { 1998-2003 } \\
\text { Bust } \\
\log \text { (price) }\end{array}$ & $\begin{array}{l}2004-2007 \\
\text { Recovery } \\
\log \text { (price) }\end{array}$ & $\begin{array}{l}2008 \\
\text { GFC } \\
\log (\text { price })\end{array}$ & $\begin{array}{l}\text { After } \\
2009 \\
\text { Boom } \\
\log \text { (price) }\end{array}$ \\
\hline $\begin{array}{l}\text { Panel A: Resi- } \\
\text { dential }\end{array}$ & (1) & (2) & (3) & (4) & (5) \\
\hline Loss & $\begin{array}{l}0.2009^{* * *} \\
(0.0337)\end{array}$ & $\begin{array}{l}0.0243^{* *} \\
(0.0103)\end{array}$ & $\begin{array}{l}0.0428^{* * *} \\
(0.0076)\end{array}$ & $\begin{array}{l}0.0396^{* *} \\
(0.0162)\end{array}$ & $\begin{array}{l}0.0729^{*} \\
(0.0374)\end{array}$ \\
\hline Estimated Value & $\begin{array}{l}1.0131^{* * *} \\
(0.0072)\end{array}$ & $\begin{array}{l}0.9941^{* * *} \\
(0.0106)\end{array}$ & $\begin{array}{l}1.0697^{* * *} \\
(0.0116)\end{array}$ & $\begin{array}{l}0.9938^{* * * *} \\
(0.0123)\end{array}$ & $\begin{array}{l}0.8940^{* * *} \\
(0.0166)\end{array}$ \\
\hline $\begin{array}{l}\text { Residuals from } \\
\text { Last Sale }\end{array}$ & $(0.0247)$ & $(0.0135)$ & $(0.0176)$ & $(0.0202)$ & $(0.0158)$ \\
\hline Holding Period & $\begin{array}{l}-0.0015^{* * *} \\
(0.0002)\end{array}$ & $\begin{array}{l}-0.0015^{* * *} \\
(0.0001)\end{array}$ & $\begin{array}{l}-0.0148^{* * *} \\
(0.0001)\end{array}$ & $\begin{array}{l}-0.0012^{\text {*** }} \\
(0.0001)\end{array}$ & $\begin{array}{l}-0.0117^{* * * *} \\
(0.0001)\end{array}$ \\
\hline $\begin{array}{l}\text { Year * District } \\
\text { FEs }\end{array}$ & $\mathrm{Y}$ & Y & $\mathrm{Y}$ & $\mathrm{Y}$ & $\mathrm{Y}$ \\
\hline $\begin{array}{r}\text { Benchmark } \\
\log \text { (price) }\end{array}$ & 1.080 & 0.544 & 0.651 & 0.810 & 1.204 \\
\hline Observations & 28,883 & 66,142 & 95,599 & 24,795 & 197,844 \\
\hline R-squared & 0.932 & 0.915 & 0.934 & 0.918 & 0.918 \\
\hline Panel B: Industrial & (1) & (2) & (3) & (4) & (5) \\
\hline Loss & $\begin{array}{l}0.2162^{* *} \\
(0.0801)\end{array}$ & $\begin{array}{l}0.1346^{* * * *} \\
(0.0421)\end{array}$ & $\begin{array}{l}0.1202^{* * * *} \\
(0.0290)\end{array}$ & $\begin{array}{l}0.1680 \\
(0.1098)\end{array}$ & $\begin{array}{l}0.3233^{* * * *} \\
(0.0528)\end{array}$ \\
\hline Estimated Value & $\begin{array}{l}1.0601^{* * *} \\
(0.0224)\end{array}$ & $\begin{array}{l}1.0126^{* * *} \\
(0.0168)\end{array}$ & $\begin{array}{l}1.0491^{* * * *} \\
(0.0192)\end{array}$ & $\begin{array}{l}1.0542^{* * *} \\
(0.0194)\end{array}$ & $\begin{array}{l}0.9930^{* * *} \\
(0.0146)\end{array}$ \\
\hline $\begin{array}{l}\text { Residuals from } \\
\text { Last Sale }\end{array}$ & $(0.0512)$ & $(0.0516)$ & $(0.0266)$ & $(0.0453)$ & $\begin{array}{l}0.6254^{* * *} \\
(0.0252)\end{array}$ \\
\hline Holding Period & $\begin{array}{l}-0.0009 \\
(0.0006)\end{array}$ & $\begin{array}{l}-0.0020^{* * *} \\
(0.0003)\end{array}$ & $\begin{array}{l}-0.0010^{* * *} \\
(0.0001)\end{array}$ & $\begin{array}{l}-0.0004^{* *} \\
(0.0002)\end{array}$ & $\begin{array}{l}-0.0001 \\
(0.0001)\end{array}$ \\
\hline $\begin{array}{l}\text { Year * District } \\
\text { FEs }\end{array}$ & $\mathrm{Y}$ & $\mathrm{Y}$ & $\mathrm{Y}$ & $\mathrm{Y}$ & $\mathrm{Y}$ \\
\hline $\begin{array}{r}\text { Benchmark } \\
\log (\text { price })\end{array}$ & 0.407 & -0.408 & 0.001 & 0.421 & 0.880 \\
\hline Observations & 3,693 & 4,856 & 7,987 & 1,530 & 13,308 \\
\hline R-squared & 0.906 & 0.859 & 0.878 & 0.878 & 0.892 \\
\hline Panel C: Office & (1) & (2) & (3) & (4) & (5) \\
\hline Loss & $\begin{array}{l}0.0521^{*} \\
(0.0299)\end{array}$ & $\begin{array}{l}0.2643^{*} \\
(0.1518)\end{array}$ & $\begin{array}{l}0.1306^{* * *} \\
(0.0284)\end{array}$ & $\begin{array}{l}0.1494^{* * *} \\
(0.0498)\end{array}$ & $\begin{array}{l}0.2548^{* * *} \\
(0.0443)\end{array}$ \\
\hline Estimated Value & $\begin{array}{l}1.0541^{* * *} \\
(0.0140)\end{array}$ & $\begin{array}{l}0.9482^{* * *} \\
(0.0185)\end{array}$ & $\begin{array}{l}1.0489^{* * *} \\
(0.0232)\end{array}$ & $\begin{array}{l}1.0558^{* * *} \\
(0.0461)\end{array}$ & $\begin{array}{l}0.9946^{* * *} \\
(0.0139)\end{array}$ \\
\hline $\begin{array}{l}\text { Residuals from } \\
\text { Last Sale }\end{array}$ & $\begin{array}{l}0.8895^{* * *} \\
(0.0252)\end{array}$ & $0.5833^{* * * *}$ & $0.7987^{* * *}$ & $\begin{array}{l}0.7438^{* * * *} \\
(0.0329)\end{array}$ & $\begin{array}{l}0.6812^{* * *} \\
(0.0132)\end{array}$ \\
\hline Holding Period & $-0.0023^{* *}$ & $-0.0024^{* *}$ & $-0.0009^{* * *}$ & $-0.0003^{* * *}$ & -0.0001 \\
\hline
\end{tabular}


Table 5 (continued)

\begin{tabular}{|c|c|c|c|c|c|}
\hline & $\begin{array}{l}\text { Before } 1997 \\
\text { Boom } \\
\log (\text { price })\end{array}$ & $\begin{array}{l}1998-2003 \\
\text { Bust } \\
\log \text { (price) }\end{array}$ & $\begin{array}{l}2004-2007 \\
\text { Recovery } \\
\log \text { (price) }\end{array}$ & $\begin{array}{l}2008 \\
\text { GFC } \\
\log (\text { price })\end{array}$ & $\begin{array}{l}\text { After } \\
2009 \\
\text { Boom } \\
\log (\text { price })\end{array}$ \\
\hline & $(0.0009)$ & $(0.0010)$ & $(0.0002)$ & $(0.0001)$ & $(0.0001)$ \\
\hline $\begin{array}{l}\text { Year * District } \\
\text { FEs }\end{array}$ & $\mathrm{Y}$ & $\mathrm{Y}$ & $\mathrm{Y}$ & $\mathrm{Y}$ & $\mathrm{Y}$ \\
\hline $\begin{array}{r}\text { Benchmark } \\
\log (\text { price })\end{array}$ & 1.004 & 0.303 & 0.651 & 0.867 & 1.241 \\
\hline $\begin{array}{l}\text { Degrees of Free- } \\
\text { dom }\end{array}$ & & & & 692 & \\
\hline Observations & 2,395 & 2,418 & 3,778 & 721 & 5,254 \\
\hline R-squared & 0.952 & 0.909 & 0.919 & 0.917 & 0.939 \\
\hline Panel D: Retail & (1) & (2) & (3) & (4) & (5) \\
\hline \multirow[t]{2}{*}{ Loss } & 0.1974 & $0.3534^{* * *}$ & $0.2505^{* * * *}$ & $0.3905^{* * *}$ & $0.2953^{* *}$ \\
\hline & $(0.1473)$ & $(0.1247)$ & $(0.0890)$ & $(0.0912)$ & $(0.1190)$ \\
\hline Estimated Value & $\begin{array}{l}1.0185^{* * * *} \\
(0.0258)\end{array}$ & $\begin{array}{l}0.9906^{* * * *} \\
(0.0525)\end{array}$ & $\begin{array}{l}1.0544^{* * * *} \\
(0.0593)\end{array}$ & $\begin{array}{l}1.0608^{* * *} \\
(0.0438)\end{array}$ & $\begin{array}{l}1.1114^{* * *} \\
(0.0238)\end{array}$ \\
\hline \multirow[t]{2}{*}{$\begin{array}{l}\text { Residuals from } \\
\text { Last Sale }\end{array}$} & $0.8098^{* * *}$ & $0.5451^{* * *}$ & $0.7046^{* * *}$ & $0.6666^{* * *}$ & $0.6845^{* * *}$ \\
\hline & $(0.0947)$ & $(0.0963)$ & $(0.0504)$ & $(0.0517)$ & $(0.0198)$ \\
\hline Holding Period & $\begin{array}{l}-0.0015 \\
(0.0017)\end{array}$ & $\begin{array}{l}-0.0041^{\text {**** }} \\
(0.0012)\end{array}$ & $\begin{array}{l}-0.0023^{* * *} \\
(0.0003)\end{array}$ & $\begin{array}{l}-0.0015^{\text {** }} \\
(0.0006)\end{array}$ & $\begin{array}{l}-0.0013^{* *} \\
(0.0005)\end{array}$ \\
\hline $\begin{array}{l}\text { Year * District } \\
\text { FEs }\end{array}$ & $\mathrm{Y}$ & $\mathrm{Y}$ & $\mathrm{Y}$ & $\mathrm{Y}$ & $\mathrm{Y}$ \\
\hline $\begin{array}{r}\text { Benchmark } \\
\log (\text { price })\end{array}$ & 0.718 & 0.432 & 0.597 & 0.561 & 0.934 \\
\hline $\begin{array}{l}\text { Degrees of Free- } \\
\text { dom }\end{array}$ & & & & 330 & \\
\hline Observations & 636 & 920 & 1,615 & 369 & 3,032 \\
\hline R-squared & 0.922 & 0.835 & 0.822 & 0.865 & 0.847 \\
\hline
\end{tabular}

The benchmark $\log$ (price) is the mean of the $\log$ (price) for transactions with expected nominal gains. Robust standard errors are clustered at district level. Degrees of freedom for regressions with less than 1,000 samples are reported. $* * *, * *, *$ denote for $1 \%, 5 \%$ and $10 \%$ significance, respectively

residential and industrial sectors than in the office and retail sectors. The weaker significance of the Loss estimation in the latter two sectors is possibly due to the limited number of observations in each period with the loss restriction.

In summary, our empirical results reveal that, while the magnitude of expected nominal losses decreases with the market heat, the loss effect moves in the opposite direction at the individual transaction level. During booming periods when the pool of potential buyers with high willingness to pay is large, loss-facing sellers with high reservation prices may still find a buyer. However, in the market downturns characterised by low demand, it is difficult for the loss-facing sellers to find buyers that are willing to accept "abnormally" high transaction prices. Consequently, sellers are 
forced to accept more "rational" prices justifiable by property features and market conditions. It thus implies that the strengths of buyers' bargaining power under different market conditions plausibly exert a channel that influences the extent to which the sellers' loss behavior affects the market transaction prices.

\section{The Aggregate Loss Effects on Property Price Indices}

\section{Construction of the Loss-effect Adjusted Property Price Indices}

While there are many loss-facing sellers in the property market, evidence about the aggregate loss effect is mixed. BG took the difference of the impact from losses and gains as the measure of loss aversion behaviour, and they found the aggregate impact negligible: The maximum effect is in the bust period, but it has only increased the market price by approximately 1.2\%. Zhou et al. (2021) adjusted for anchoring to the previous purchase price, including but not limited to loss aversion, and they found that the anchoring effect significantly decreases the market volatility across the property cycle. Still, there are no conclusive evidence explaining the relevance of the aggregate loss effect to the market cycle.

Our empirical evidence on the individual-level effect of expected losses across the cycle sheds new insights on the puzzle of the aggregate impact: We find that the individual loss effect on transaction prices in the boom period is stronger than in the bust period, but the total number of sellers facing losses and the average loss per seller are also smaller in the boom period. The aggregate impact is thus influenced by the interaction of both changes in the magnitude of individual impact and the number of loss-facing sellers. We attempt to reveal this by investigating the aggregate loss effect on the price index in the four property sectors in Hong Kong.

We use the repeat sales index derived from the paired repeat transactions in our sample period as the benchmark, which is computed using the widely applied methodology proposed by Case and Shiller (1989). ${ }^{12}$ We employ a similar empirical strategy developed by BG and Zhou et al. (2021) to calculate the loss-effect adjusted property price index. The difference is that, unlike Zhou et al. (2021) that consider both the effects of gains and losses, our focus is on loss effects and only the coefficients of losses are included in the price index adjustment. Specifically, we decompose the aggregate impact into three components: weight (\%SellerWithLoss), magnitude $(E($ Loss $))$, and coefficient $(\gamma)$ :

$$
\text { Aggregate Impact }=\% \text { SellerWithLoss } * \text { E(Loss }) * \gamma
$$

In each year, we first calculate the percentage of sellers that are facing an expected loss (i.e., the weight), based on Eq. (2). Then we calculate the

\footnotetext{
12 The Rating and Valuation Department (RVD) of Hong Kong also publishes a transaction-based index for all the four major property sectors, which uses the official land registry records and virtually covers all property transactions (Chau et al., 2005). Our derived repeat sales index closely follows the trend of this RVD index, which is plotted in Appendix Figure A1.
} 

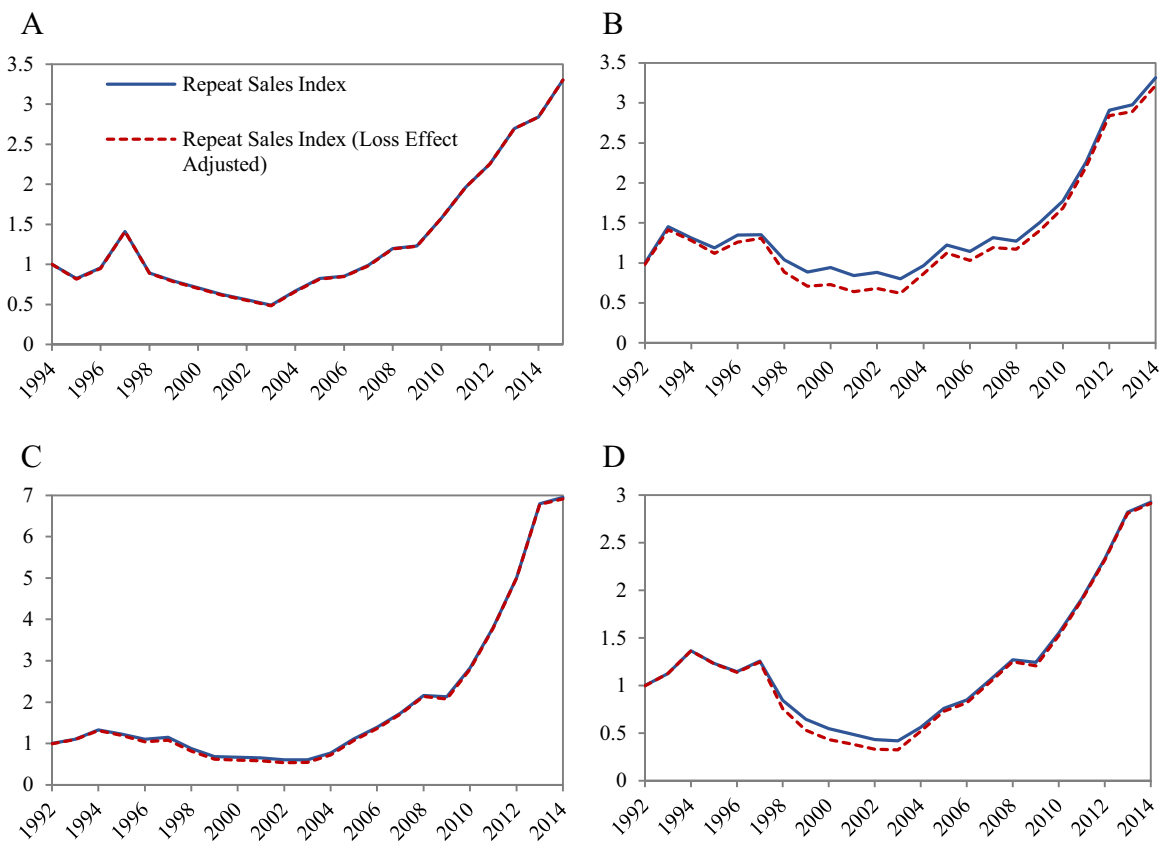

Fig. 2 Aggregate Loss Effects on Hong Kong Market Prices Across Four Property Sectors (A) Residential Property Price Index (B) Retail Property Price Index (C) Industrial Property Price Index (D) Office Property Price Index

expectation of the loss amount (i.e., the magnitude) given that the seller faces an expected loss. Next, we calculate the individual-level impact of a unit amount of expected loss on the transaction price (i.e., the coefficient), following the specification in Eq. (3). Due to insufficient data on a yearly basis, we use the coefficient in each period instead, which are reported in Table 5. Finally, the aggregate adjustment factor to the property price index is calculated as the product of the weight, the magnitude and the coefficient, and the repeat sales index in each year is adjusted accordingly. ${ }^{13}$

Unlike the individual-level loss effect of which the magnitude is larger in the boom period, we find the aggregate loss effect is more prominent during the bust period. Figure 2 plots the original repeat sales index and the loss-effect adjusted repeat sales index for the four property sectors in Hong Kong. In the year of 2003 during the bust period, the loss behaviour increases the transaction prices (i.e., reduces the price declines) by approximately $1.60 \%$ in the residential sector, $11.55 \%$ in the industrial sector, $29.07 \%$ in the office sector, and $23.01 \%$ in the retail sector. However, in 2014 when the market is booming, the loss behaviour only raises the transaction prices by $0.02 \%$ in the residential sector, $0.52 \%$ in the industrial sector,

\footnotetext{
13 Technically, we follow BG and take the log of the repeat sales index first. Then we subtract the lossaversion adjustment factor, and exponentiate the adjusted index back to the straight levels.
} 
$0.46 \%$ in the office sector, and $2.98 \%$ in the retail sector. This implies that the considerable increase in the number of loss-facing sellers mainly drives the loss effect on the aggregate market during the bust period. Appendix Figure A2 plots changes in the percentage of Loss sales and the magnitude of the Loss sales across the four property sectors. Taking the residential sector for an example, the percentage of loss-facing sellers (i.e., the weight) in the bust period from 1998 to 2003 is $89.51 \%$, which is over 9 times of the percentage in the boom period after 2009 (see Table 4). Also, the expected loss of these loss-facing sellers in the bust period is significantly larger than that in the boom period. Although the impact of a unit expected loss on transaction price (i.e., the coefficient) is only 0.0243 in the bust period, which is around $1 / 3$ of the coefficient in the boom period, the overall aggregate loss effect is still stronger in the bust period.

The adjusted repeat sales index also reveals that, at the aggregate market level, the loss effect is much stronger in the three commercial sectors than in the residential sector. On the one hand, this can be explained by our findings at the individual level that comparable transaction information impacts the market's adjustment of loss effect on the real transaction prices (Table 3). On the other hand, it is also attributable to the larger market volatility of the commercial property markets in Hong Kong. The average percentage of sellers with expected losses is smaller in the residential sector than in the other three sectors. As reported in Table 1, the percentage is $34.7 \%$ in the residential property market, $38.4 \%$ in the industrial property market, $43.7 \%$ in the office property market, and $42.7 \%$ in the retail property market. Also, the expected loss amount given an expected loss occurs is also smaller in the residential sector than in the other three commercial sectors. The expected loss amount in the logarithmic form is $0.371,0.575$, 0.604 and 0.595 in the residential, industrial, office and retail property market, respectively.

Our estimated aggregate loss effect in Hong Kong's residential market is comparable in magnitude to that was estimated in the U.S. by Zhou et al. (2021). ${ }^{14}$ Table 6 reports the estimated loss effect on the residential markets in the U.S. and Hong Kong during the bust period (i.e., 2003 in Hong Kong and 2012 in the U.S.), when the aggregate market impacts are found to be larger. Indeed, Zhou et al. (2021) focused on the overall anchoring effect of purchase prices on the subsequent transaction prices, which include the impact of both nominal losses and gains. It may be concerned that solely extract their estimate of the impact from nominal losses may not be comparable to our estimate of loss effect without considering the gain impact. Therefore, we also calculate the individual loss effect with the gain impact controlled by the inclusion of the variable of Gain, defined as the expected loss of the seller being truncated above at zero.

\footnotetext{
${ }^{14}$ For the commercial sectors, BG estimate that in the U.S., the individual-level impact of loss aversion on all commercial properties is 0.380 , which lies in the range of our estimates using sub-sectors of commercial properties in Hong Kong. Unfortunately, we cannot compare the aggregate impact of loss aversion on the commercial property market in Hong Kong with that in the U.S, because BG does not report the aggregate impact solely from loss aversion (i.e., excluding the impact from nominal gains) on commercial property market in the U.S.
} 
Table 6 Comparison between the Aggregate Loss Effects in the U.S. and Hong Kong during the Bust Period

\begin{tabular}{|c|c|c|c|c|c|}
\hline & (1) & (2) & (3) & (4) & (5) \\
\hline & U.S & HK & HK & HK & HK \\
\hline & Residential & Residential & Retail & Industrial & Office \\
\hline & 2012 & 2003 & 2003 & 2003 & 2003 \\
\hline Coefficient Estimate of Expected Loss & I & 0.024 & 0.353 & 0.135 & 0.264 \\
\hline $\begin{array}{l}\text { Coefficient Estimate of Expected Loss-with } \\
\text { the variable of Gain included }\end{array}$ & 0.046 & 0.013 & 0.384 & 0.139 & 0.269 \\
\hline Loss-Facing Sellers (\%) & 0.686 & 0.959 & 0.789 & 0.898 & 0.947 \\
\hline $\log$ (Expected Loss) & 0.290 & 0.683 & 0.743 & 0.905 & 1.019 \\
\hline Original Price Index & 1.079 & 0.490 & 0.800 & 0.602 & 0.420 \\
\hline Adjusted Price Index & / & 0.482 & 0.651 & 0.539 & 0.326 \\
\hline $\begin{array}{l}\text { Adjusted Price Index-with the variable of } \\
\text { Gain }\end{array}$ & 1.069 & 0.485 & 0.639 & 0.537 & 0.324 \\
\hline Change & I & $1.60 \%$ & $23.01 \%$ & $11.55 \%$ & $29.07 \%$ \\
\hline Change - with the variable of Gain & $0.90 \%$ & $0.85 \%$ & $25.22 \%$ & $11.92 \%$ & $29.70 \%$ \\
\hline
\end{tabular}

Statistics in Column (1) are extracted from Tables 5 \& 6 in Zhou et al. (2021), which are estimated using the residential transactions in Connecticut. Column (1) include transactions in 2012, which is the last year of the bust period defined by Zhou et al. (2021). Columns (2) - (5) include transactions in Hong Kong in 2003, which is also the last year of the bust period from 1998 to 2003. $\log$ (Expected Loss) denotes average loss amount in log form that the sellers face given expected losses occur. Loss Adjustment Factor is the product of Coefficient of Loss Effect, Loss-Facing Sellers (\%) and log (Expected Loss). Following BG, the Adjusted Price Index is calculated by first taking logarithm of the Price Index, subtracting the Loss Adjustment Factor, and finally being converted back to the straight levels

In Table 6, the first row reports the coefficient estimates of the Loss variable from Table 5, while the second row gives the estimates with the impact of gains controlled. We find the individual impact, reflected by the coefficient estimate of loss effect $(\gamma)$, on Hong Kong's residential transactions (Column (2) of Table 6) is smaller than that in the U.S. (Column (1) of Table 6) with or without the gain impact controlled. It is because at the individual transaction level, considering that more comparable market information from neighborhood residential units exists in the very dense urban context in Hong Kong, it may be difficult for Hong Kong property sellers with expected losses to earn a higher price. However, the aggregate loss effect on Hong Kong's residential market $(0.85 \%)$ is very similar to than that in the U.S. $(0.90 \%)$. This is because, in Hong Kong where the property market is more volatile than that in the U.S., sellers are more likely to face a loss in the bust period, which increases the overall aggregate-level impact despite of the smaller impact at the individual transaction level than in the U.S. For example, $87.8 \%$ of the Hong Kong residential property sellers face nominal losses in 2003, while the figure is only 68.6 percent in the U.S. when the burst period ends in 2012. We also document the aggregate loss effect with the impact of gains being controlled in the three commercial sectors and they have larger magnitudes 
than in the impact in the residential market, as shown in the last three columns of Table 6. The findings are consistent with what are observed in Fig. ${ }^{15}$

\section{Limitations}

First of all, the accuracy of our loss-effect adjusted index is constrained due to the lack of early transaction data. In generating the loss-effect adjusted index, only the paired repeat transactions are used to calculate the percentage of loss-facing sellers and their expected losses, but a large proportion of transactions in the early years of the sample period do not have information on the prior purchase prices (i.e., these units were initially purchased before the start of our sample period). Specifically, for repeat sales in the bust period from 1997 to 2003, we can only identify the expected losses for the sellers who purchased the units after 1992. Since Hong Kong's property markets had been continuously increasing from 1980 to 1992 (see Fig. 1), excluding the sellers who purchased in earlier years with lower prices is likely to cause overestimation of loss-facing sellers and the expected losses in the bust periods.

To partially alleviate this concern, we conduct a robustness check by only including the paired repeat transactions with the holding period of less than 10 years (denoted as the truncated sample). Since our sampling period starts from 1992, this allows a more balanced sampling for comparing the by-year loss effect, especially from 2003 onward. The repeat sales index and the adjustment factors for the loss effect are modified accordingly. Appendix Figure A3 plots the corresponding repeat sales index and the loss-effect adjusted index using the truncated sample. We compare the by-year adjustment factors derived from the full paired samples and from the truncated samples, which are reported in Appendix Table B10. We find that, for the truncated sample, the aggregate loss effect remains stronger during the bust period, which indicates that our main finding is robust.

Secondly, the estimates of a unit expected loss on transaction price in the office and retail sectors, where fewer transactions occurred, may also be a concern. In accordance with the tests in Sect. 6, the coefficient estimates on expected losses over the property cycle are less stable in the office and retail sectors than in the residential and industrial sectors. This may pose a threat to the accuracy of loss effect estimates, thus causing bias in aggregating the loss effect on the overall market.

\section{Conclusions and Discussions}

Built upon the insights of GM, this paper provides new evidence on the importance of loss behavior on the property market. Our results by using a comprehensive dataset of Hong Kong property transactions suggest significant loss effects on

\footnotetext{
15 The aggregate effect of expected gains is much smaller in the bust periods in comparison to the aggregate effect of expect losses: $-0.003 \%$ for residential, $-2.08 \%$ for retail, $-0.30 \%$ for industrial, and $-0.54 \%$ for office sector in the Hong Kong property market, respectively. Future studies should explore whether the aggregate effect of expected gains has different dynamics across cycles.
} 
transaction prices across the residential, industrial, office, and retail sectors. We also find the loss effect to be stronger in the commercial market than in the residential market where there is abundant comparable transaction information to help reduce the mispricing of the target property. Combined with the study of BG, we shed light on the importance of sellers' loss behavior in the commercial property market where professional investors occupy.

We also examine variations in the loss effects in a large boom-bust cycle across different property sectors. We find the loss effect on the individual transaction prices to be more prominent in the boom period than in the bust period. But when combining the percentage of sellers facing an expected loss, the expectation of the loss amount, and the impact of a unit amount of expected loss on the transaction price in the aggregate market analysis, the loss effect turns stronger in the bust period than in the boom period. That is, the loss effect reduces aggregate price declines in market downturns, the effect of which is particularly strong in the commercial property sectors. These results suggest a role of loss behaviors in accounting for aggregate property market dynamics.

Our effort of examining the interaction between the loss effect and different market conditions also provides fresh insights in understanding why loss behaviors can affect market prices. Based on the reduced-form regression results, we are able to relate it to limited market information and the heat of the market. Admittedly, there exist some limitations of this study, which need further investigation with better quality of data in future studies. In particular, the accuracy of the estimated loss effect is constrained because we don't have the assessed property value like Zhou et al., $(2020,2021)$ to deal with unobserved features but mostly relying on GM's approach combined with Anerberg's (2011) improvement. This might particularly be an issue in the commercial sectors with relatively fewer transactions and inadequate quality control.

Supplementary Information The online version contains supplementary material available at https://doi. org/10.1007/s11146-021-09851-3.

Acknowledgements We thank Prof. Kwong Wing Chau from the Department of Real Estate and Construction, The University of Hong Kong for providing us with the Hong Kong property transaction data. We also thank Martin Hoesli, Rose Lai, the anonymous reviewer, and participants at the 2020 Real Estate Finance and Investment Symposium for their insightful comments. We are responsible for all remaining errors.

Authors' contribution Not applicable.

Funding Not applicable.

Data Availability Not applicable.

Code Availability Not applicable.

\section{Declarations}

Conflicts of Interest As far as we know, there are no conflicts of interest in the paper. 
Open Access This article is licensed under a Creative Commons Attribution 4.0 International License, which permits use, sharing, adaptation, distribution and reproduction in any medium or format, as long as you give appropriate credit to the original author(s) and the source, provide a link to the Creative Commons licence, and indicate if changes were made. The images or other third party material in this article are included in the article's Creative Commons licence, unless indicated otherwise in a credit line to the material. If material is not included in the article's Creative Commons licence and your intended use is not permitted by statutory regulation or exceeds the permitted use, you will need to obtain permission directly from the copyright holder. To view a copy of this licence, visit http://creativecommons.org/licen ses/by/4.0/.

\section{References}

Andersen, S., Badarinza, C., Liu, L., Marx, J., \& Ramadorai, T. (2021). Reference dependence in the housing market. Working paper available at SSRN 3396506.

Anenberg, E. (2011). Loss aversion, equity constraints and seller behavior in the real estate market. Regional Science and Urban Economics, 41(1), 67-76.

Anenberg, E. (2016). Information frictions and housing market dynamics. International Economic Review, 57(4), 1449-1479.

Bao, H. X., \& Meng, C. C. (2017). Loss aversion and housing studies. Journal of Real Estate Literature, 25(1), 49-75.

Barberis, N. C. (2013). Thirty years of prospect theory in economics: A review and assessment. Journal of Economic Perspectives, 27(1), 173-196.

Ben-David, I., \& Hirshleifer, D. (2012). Are investors really reluctant to realize their losses? Trading responses to past returns and the disposition effect. The Review of Financial Studies, 25(8), 2485-2532.

Bokhari, S., \& Geltner, D. (2011). Loss aversion and anchoring in commercial real estate pricing: Empirical evidence and price index implications. Real Estate Economics, 39(4), 635-670.

Bracke, P., \& Tenreyro, S. (2021). History dependence in the housing market. American Economic Journal: Macroeconomics, 13(2), 420-443.

Carrillo, P. E. (2013). To sell or not to sell: Measuring the heat of the housing market. Real Estate Economics, 41(2), 310-346.

Case, K., \& Shiller, R. (1989). The Efficiency of the Market for Single-Family Homes. American Economic Review, 79(1), 125-137.

Chang, T. Y., Solomon, D. H., \& Westerfield, M. M. (2016). Looking for someone to blame: Delegation, cognitive dissonance, and the disposition effect. The Journal of Finance, 71(1), 267-302.

Chau, K. (1997). Political uncertainty and the real estate risk premiums in Hong Kong. Journal of Real Estate Research, 13(3), 297-315.

Chau, K., Wong, S., Yiu, C., \& Leung, H. (2005). Real estate price indices in Hong Kong. Journal of Real Estate Literature, 13(3), 337-356.

Clapp, J. M., Lu-Andrews, R., \& Zhou, T. (2018). Anchoring to Purchase Price and Fundamentals: Application of Salience Theory to Housing Cycle Diagnosis. Real Estate Economics.

Dhar, R., \& Zhu, N. (2006). Up close and personal: Investor sophistication and the disposition effect. Management Science, 52(5), 726-740.

Einiö, M., Kaustia, M., \& Puttonen, V. (2008). Price setting and the reluctance to realize losses in apartment markets. Journal of Economic Psychology., 2(1), 19-34.

Engelhardt, G. (2003). Nominal loss aversion, housing equity constraints, and household mobility: Evidence from the United States. Journal of Urban Economics., 53(1), 171-195.

Genesove, D., \& Mayer, C. (1997). Equity and Time to Sale in the Real Estate Market. American Economic Review, 87(3), 255-269.

Genesove, D., \& Mayer, C. (2001). Loss aversion and seller behavior: Evidence from the housing market. The Quarterly Journal of Economics, 116(4), 1233-1260.

Glaeser, E. L., \& Nathanson, C. G. (2017). An extrapolative model of house price dynamics. Journal of Financial Economics, 126(1), 147-170. 
Grinblatt, M., \& Keloharju, M. (2001). What makes investors trade? The Journal of Finance, 56(2), 589-616.

Han, L., \& Strange, W. C. (2016). What is the role of the asking price for a house? Journal of Urban Economics, 93, 115-130.

Haurin, D., McGreal, S., Adair, A., Brown, L., \& Webb, J. (2013). List price and sales prices of residential properties during booms and busts. Journal of Housing Economics, 22(1), 1-10.

Leung, T., \& Tsang, K. (2013). Anchoring and loss aversion in the housing market: Implications on price dynamics. China Economic Review., 24, 42-54.

Leung, C. K. Y. (2015). Availability, affordability and volatility: The case of the Hong Kong housing market. International Real Estate Review, 18(3), 383-428.

Ling, D. C., Naranjo, A., \& Petrova, M. T. (2018). Search costs, behavioral biases, and information intermediary effects. The Journal of Real Estate Finance and Economics, 57(1), 114-151.

Northcraft, G. B., \& Neale, M. A. (1987). Experts, amateurs, and real estate: An anchoring-and-adjustment perspective on property pricing decisions. Organizational Behavior and Human Decision Processes, 39(1), 84-97.

Odean, T. (1998). Are investors reluctant to realize their losses? The Journal of Finance, 53(5), $1775-1798$.

Shefrin, H., \& Statman, M. (1985). The disposition to sell winners too early and ride losers too long: Theory and evidence. The Journal of Finance, 40(3), 777-790.

Stein, J. C. (1995). Prices and trading volume in the housing market: A model with down-payment effects. The Quarterly Journal of Economics, 110(2), 379-406.

Tversky, A., \& Kahneman, D. (1979). Prospect theory: An analysis of decision under risk. Econometrica, 47(2), 263-291.

Wong, S. K., Li, L., \& Monkkonen, P. (2020). Developers' Market Power: How do Developers Price New Housing in a Highly Oligopolistic City? International Real Estate Review, 22(3), 307-332.

Yavas, A., \& Yang, S. (1995). The strategic role of listing price in marketing real estate: Theory and evidence. Real Estate Economics, 23(3), 347-368.

Zhou, T., Clapp, J. M., \& Lu-Andrews, R. (2020). Do Sellers with Expected Losses Obtain a Premium Price? Really? Working paper available at SSRN 3534732.

Zhou, T., Clapp, J. M., \& Lu-Andrews, R. (2021). Is the behavior of sellers with expected gains and losses relevant to cycles in house prices? Journal of Housing Economics, 52, 101750.

Publisher's Note Springer Nature remains neutral with regard to jurisdictional claims in published maps and institutional affiliations. 